\title{
The changing pattern of fever of unknown origin in the Republic of North Macedonia
}

\author{
MILE BOSILKOVSKI, MARIJA DIMZOVA, MARIJA CVETKOVA, \\ KOSTADIN POPOSKI, KATERINA SPASOVSKA, IVAN VIDINIC \\ University Hospital for Infectious Diseases and Febrile Conditions, Medical Faculty \\ "Ss Cyril and Methodius" University, Skopje, Republic of North Macedonia
}

\begin{abstract}
Introduction. The study aimed to compare the etiologic spectrum of diseases causing fever of unknown origin (FUO) and methods for definitive diagnosis in a tertiary care hospital in the Republic of North Macedonia during two different time periods.

Patients and methods. There were analysed retrospectively the causes for FUO and final diagnostic approaches in 185 patients with classic FUO that were treated at the University Hospital for Infectious Diseases in Skopje during two time periods. Seventy nine patients were treated during 1991 to 1995 and 106 patients during 2011 to 2015 .

Results. When comparing these two periods, infections were present in $46.8 \%$ and $29.2 \%(\mathrm{p}=$ $0.014)$, non-infective inflammatory disorders in $22.8 \%$ and $25.5 \%(\mathrm{p}=0.674)$, neoplasms in $10.1 \%$ and $13.2 \%(\mathrm{p}=0.522)$, miscellaneous in $8.9 \%$ and $12.3 \%(\mathrm{p}=0.461)$ and undiagnosed cases in $11.4 \%$ and $19.8 \%(p=0.124)$, respectively. The most common causes for FUO during the first period were abscesses $(8.9 \%)$, tuberculosis and systemic lupus erythematosus $(7.6 \%$ each), whereas in the second period the commonest causes were adult onset Still disease and solid organ neoplasm (7.6\% each), polymyalgia rheumatica, abscesses and visceral leishmaniasis $(5.7 \%$ each). The newer imaging techniques and clinical course evaluation had superior diagnostic significance during the second period.

Conclusion. A changing pattern of diseases causing FUO during the examined periods was evident. Infections continue to be the most common cause but with decreasing incidence when compared to 20 years ago. Even nowadays clinical evaluation and follow-up still remain the vital diagnostic tools in determining the etiology of FUO.
\end{abstract}

Key words: Adult onset Still disease; Diagnosis; Fever; Infection; Neoplasm.

\section{INTRODUCTION}

Fever of unknown origin (FUO) is a clinical entity which comprises over 200 diseases as possible etiologic causes $[1,2]$. Even today, same as decades ago, FUO continues to be a frustrating condition both for the patients and the physicians. Patients are preoccupied with the uncertainty and the fear of the possible cause for the elevated temperature and their outcome, while the later are professionally challenged with establishing the diagnosis, something that often remains undetermined or has been established after consuming a substantial amount of time, effort and funds.

The aetiology of FUO is determined by multiple causes like geographic, economic and demographic characteristics, used definition and diseases classification, accessibility of diagnostic tools and the development of new antimicrobials and immunomodulating agents [3]. It has been shown that the immense expansion of the medical science and the improvement of life quality and expectancy, existent these last decades, have not much contributed in overcoming FUO, but at the same time have influenced the causative spectrum of diseases $[4,5]$. Commonly reported changing pattern in concordance with the investigated period is subsequent with the changes in the frequency of the diagnostic groups as well as the diseases causing FUO [4, 6-8]. Factors which have influenced the diagnostic spectrum over time are complex, including discovering of new or emerging diseases [8], or modification of the clinical presentation of the existing ones $[3,9,10]$; advances in diagnostic techniques and development of new diagnostic tools $[4,5,11]$; alterations of socio-economic and demographic characteristics of the population [11]; as well as life styles amendments and increased medical care [4].

Fever of unknown origin (FUO) pattern has not been widely investigated in the Republic of North Macedonia and its neighbouring countries. 
Not many published data exist [3, 12-17]. On the other hand, during the last 30 years, the Republic of North Macedonia was subjected to pronounced transitional processes, characterized with different and specific socio-economic, demographic and political matters. Thus, it was a great challenge not only to define the etiologic spectrum of causes for FUO but also to explore the dynamic of these conditions according to the studied period in a tertiary care hospital in the Republic of North Macedonia.

\section{MATERIAL AND METHODS}

In this retrospective study we analysed the main demographic characteristics, the causes of FUO and the final diagnostic approach in 185 patients with classic FUO, that were treated at the Department for fever of unknown origin at the University Hospital for Infectious Diseases and Febrile Conditions in Skopje in two periods of time separated with a 20 years long interval. In the time period from 1991 to 1995 there were treated 79 patients total (group 1), and in the time period from 2011 to 2015 - 106 patients (group 2). For several decades now the University Hospital for Infectious Diseases and Febrile Conditions is the only accredited healthcare institution in the country for diagnosing adult patients with FUO. The inclusion criteria were: age more than 14 years, axillary fever of at least $37.5^{\circ} \mathrm{C}$ associated with laboratory parameters of inflammation on several occasions, fever duration of more than 21 days, failure to reach a diagnosis after the initial diagnostic workup and absence of immunosuppression.

The initial diagnostic work-up included detailed medical history, thorough physical examination, complete biochemical, hematological tests and urine analysis, at least two blood cultures, urine culture, serology for brucellosis, anti HIV test, chest x-ray, abdominal ultrasonography and tuberculin skin test [3]. After fulfilling the diagnostic criteria for FUO, patients were subjected to further diagnostic workup which included repeated inquiring and daily physical reexamination, microbiological cultures and smears, serological tests (microbiological and immunological), imaging techniques, endoscopic procedures, histology, as well as the clinical course evaluation and empiric therapy response. Sometimes the patients were submitted to reiteration of some of the already performed diagnostic tests. The diagnostic protocol did not include rigid diagnostic algorithm and in the individualized approach to each patient local epidemiological characteristics and the presence of potential diagnostic clues were taken into account [3]. Furthemore, in the absence of potential diagnostic clues, during diagnostic work-up, invasive diagnostic tests were used when other non-invasive investigations did not contribute to reach the diagnosis.

The causes of FUO were classified into 5 diagnostic categories: infections, neoplasm, noninfective inflammatory disorders (NIID), miscellaneous, and undiagnosed. We compared the basic demographic characteristic, fever duration before the initial evaluation, the causes of FUO and diagnostic approaches used to make the final diagnosis. The study was approved by the Medical Faculty Review Board.

Patients' age and fever duration before the inclusion in the study were presented using median and range values. All other parameters were presented as frequencies and percentages. Chi-squared test and Fisher exact test (when appropriate) were used for qualitative and Mann-Whitney $U$ test for quantitative variables. $\mathrm{P}$ values $<0.05$ were considered significant.

\section{RESULTS}

During the first period in our hospital were hospitalized 9238 adult patients with various diagnoses, $79(0.86 \%)$ of them fulfilled criteria for FUO, whereas during the second period were hospitalized 11132 patients, and $106(0.95 \%)$ of them had diagnosis of FUO $(\mathrm{p}=0.467)$. Thirty six different causes for FUO were discovered in both groups: 28 in the first and 27 in the second group. Forty four $(55.7 \%)$ out of 79 patients in group 1 and $62(58.5 \%)$ out of 106 patients in group 2 were males $(\mathrm{P}=0.704)$. The patients in the first and second time period were old median 38 and 52.5, range 16-76 and 15-85 years, respectively $(\mathrm{P}=$ $0.011)$. Seven $(8.9 \%)$ patients from group 1 and 23 $(21.7 \%)$ from group 2 were older than 64 years $(\mathrm{P}=0.019)$. Fever duration before the inclusion in the study was median 30 , range $21-730$ days for both groups $(P=0.074)$. In all patients at least one antimicrobial treatment was explored prior to the admission in the study.

As shown on Table 1, there was a significant decreasing incidence of infections as a cause during 
the second time period $(\mathrm{P}=0.014)$. In this period undiagnosed cases had higher occurrence compared to the first one, although without significant difference $(P=0.124)$. In the second time period a decreasing number of cases with tuberculosis, abscesses, urinary tract infection and sepsis was evident and increasing frequency of cases with visceral leishmaniasis and Cytomegalovirus infection. Likewise, in group 2 a slight raise of NIID was noted mainly due to Adult onset Still disease, polymyalgia rheumatica and reactive arthritis cases, but decreasing occurrence of systemic lupus erythematosus and autoimmune hepatitis. There was also a slightly increasing trend of malignant diseases in group 2, especially of lymphomas and solid organ malignancies. Some conditions resulting in FUO were noted only in the first time period (urinary tract infection, typhoid fever, Q fever, Mycoplasma infection, osteomyelitis, sarcoidosis, polymyositis, factitious fever), and others only in the second time period (Clostridium difficile infection, vasculitis, erythema nodosum, deep vein phlebothrombosis, ulcerative colitis, idiopathic pericarditis and PFAPA syndrome), mainly with accidental frequency (Table 1).

Diagnostic tools and procedures employed in establishing the final diagnosis (Table 2) were diversely represented in both time periods, but without statistical significance $(\mathrm{P}=0.582)$. In group 2, there was pronounced impact of clinical evaluation and computed tomography and magnetic resonance imaging in establishing the diagnosis.

Table 1

The diagnostic groups and causes for FUO during the examined periods

\begin{tabular}{|c|c|c|c|}
\hline Causes $^{\text {a }}$ & $\begin{array}{c}1991-1995 \\
\text { (79 patients) }\end{array}$ & $\begin{array}{c}2011-2015 \\
\text { (106 patients) }\end{array}$ & $\mathbf{P}$ \\
\hline INFECTION & $37(46.8)$ & $31(29.2)$ & \multirow[t]{10}{*}{0.014} \\
\hline Abscess & $7(8.9)$ & $6(5.7)$ & \\
\hline Tuberculosis & $6(7.6)$ & $4(3.8)$ & \\
\hline Subacute endocarditis & $3(3.8)$ & $5(4.7)$ & \\
\hline Visceral leishmaniasis & $2(2.5)$ & $6(5.7)$ & \\
\hline Sepsis & $4(5.1)$ & $1(0.9)$ & \\
\hline Urinary tract infection & $5(6.3)$ & 0 & \\
\hline Odontogenic infection & $2(2.5)$ & $3(2.8)$ & \\
\hline Cytomegalovirus infection & $1(1.3)$ & $3(2.8)$ & \\
\hline Other $^{\mathrm{b}}$ & $7(8.9)$ & $3(2.8)$ & \\
\hline NIID & $18(22.8)$ & $27(25.5)$ & 0.674 \\
\hline Adult onset Still disease & $4(5.1)$ & $8(7.6)$ & \\
\hline Systemic lupus erythematosus & $6(7.6)$ & $3(2.8)$ & \\
\hline Polymyalgia rheumatica & 0 & $6(5.7)$ & \\
\hline Reactive arthritis & $1(1.3)$ & $4(3.8)$ & \\
\hline Rheumatoid arthritis & $2(2.5)$ & $2(1.9)$ & \\
\hline Autoimmune hepatitis & $3(3.8)$ & $1(0.9)$ & \\
\hline Other $^{\mathrm{c}}$ & $2(2.5)$ & $3(2.8)$ & \\
\hline NEOPLASTIC DISORDERS & $8(10.1)$ & $14(13.2)$ & 0.522 \\
\hline Solid organ neoplasm & $3(3.8)$ & $8(7.6)$ & \\
\hline Lymphoma & $2(2.5)$ & $5(4.7)$ & \\
\hline Leucosis & $3(3.8)$ & $1(0.9)$ & \\
\hline MISCELLANEOUS & $7(8.9)$ & $13(12.3)$ & 0.461 \\
\hline Subacute thyroiditis & $2(2.5)$ & $2(1.9)$ & \\
\hline Deep vein phlebothrombosis & 0 & $3(2.8)$ & \\
\hline Lung embolia & $1(1.3)$ & $2(1.9)$ & \\
\hline Other $^{d}$ & $4(5.1)$ & $6(5.7)$ & \\
\hline NO DIAGNOSIS & $9(11.4)$ & $21(19.8)$ & 0.124 \\
\hline
\end{tabular}

${ }^{\mathrm{a}}$ Data are in number (percentage)

${ }^{\mathrm{b}}$ Period 1: two cases with typhoid fever and Q fever, one case with Mycoplasma infection, pansinusitis and osteomyelitis; Period 2: two cases with pansinusitis; one case with Clostridium difficile infection.

${ }^{\mathrm{c}}$ Period 1: one case with sarcoidosis and polymyositis; Period 2: two cases with urticaria vasculitis one case with erythema nodosum.

${ }^{\mathrm{d}}$ Period 1: two cases with factitious fever, one case with drug fever and inflammatory bowel disease (IBD); Period 2: two cases with idiopathic pericarditis and IBD, one case with drug fever and Periodic Fever Adenitis Pharyngitis Aphthous Ulcer (PFAPA) syndrome. 
Table 2

Method for final diagnosis in patients with FUO during the examined periods

\begin{tabular}{|c|c|c|}
\hline Diagnostic method $^{a}$ & $\begin{array}{c}1991-1995 \\
(70 \text { patients) }\end{array}$ & $\begin{array}{c}\text { 2011-2015 } \\
\text { (85 patients) }\end{array}$ \\
\hline Biochemistry \& haematology \& immunology & $11(15.7)$ & $10(11.8)$ \\
\hline Microbiology (culture, smear, serology \& skin tests) & $13(18.6)$ & $12(14.1)$ \\
\hline Imaging techniques & $21(29.9)$ & $26(30.5)$ \\
\hline Radiography & $5(7.1)$ & $3(3.5)$ \\
\hline Computed tomography \& magnetic resonance imaging & $5(7.1)$ & $12(14.1)$ \\
\hline Ultrasound & $8(11.4)$ & $11(12.9)$ \\
\hline Scintigraphy & $3(4.3)$ & 0 \\
\hline Endoscopy & $2(2.8)$ & $2(2.4)$ \\
\hline Histology & $12(17.2)$ & $13(15.3)$ \\
\hline Clinical course and/or empiric therapy response & $11(15.7)$ & $22(25.9)$ \\
\hline
\end{tabular}

${ }^{a}$ Data are in number (percentage)

\section{DISCUSSION}

With this retrospective study we made an attempt to evaluate the dynamics of both the causative diseases for FUO and of the methods which contributed to establishing the final diagnosis in patients treated in a tertiary care institution in the Republic of North Macedonia during two different time periods over an interval of 20 years. To our knowledge this is an only study in literature with this type of methodology, performed in a same hospital, by the same medical team and with a time interval between the studied periods. In this way we preserved the same approach to the patients in both time periods including the definition of FUO and used diagnostic protocols and methods, since from the second time period, there has not been a significant progress in the implementation of the more sophisticated and contemporary diagnostic procedures. Namely, in this period, in the political arena the country's external political and inner ethnic issues had higher priority than health care. Comparisons of diagnostic categories of FUO over time were made in few other studies; still, either the studies were conveyed at the same hospital but by different authors $[18,19]$ or they were performed by the same authors but in different institutions [20]. In addition, in some studies the characteristics of FUO were investigated in periods where there was no substantial time difference, i.e. with the completion of one period, a new period of study was started [21-24]. Also, there are studies where one's own clinical material was compared with previously published data from the same or different regions $[4,5,24,25]$.

In our study, the patients from the second time period were significantly older which can partially explain the changed etiological spectrum of FUO causes with increased frequency of solid organ neoplasms, polymyalgia rheumatica and deep vein thrombosis. Similar age distribution to the one found in our study was described by Barbado et al. [23], while in other studies no age differences between the studied periods were noted [22, 24].

The most common diseases causing FUO in our patients, for the major part were the same as the ones described in different parts of the world [1, 26-28]. Independently, this study showed a significant regression in the frequency of infections compared to the one two decades ago. The reason for this declining trend in the first place could be prescribed to improved diagnostic methods and their interpretation during the second time period, but also to the possibility of epidemiological transition in the geographical region and empirical use of newer antimicrobials. Paradoxically, in spite of the microbiological diagnostic improvement, cases with UTI and sepsis may still remain part of FUO, as a result of initial negative cultures due to abundant empirical use of antimicrobial therapy. Several literature data, especially from developed countries, note the decreasing trend of infections and the rising frequency of NIID as causative factors for FUO during the last decades $[4,24]$. Despite the decline of infections in the recent times, they still remain a leading category for $\mathrm{FUO}$, especially in community hospitals in developed and in tertiary health care institutions in developing countries [13, $18,19,21]$, as was the case in our study, too. During the last decades, a decreasing trend was noted in malignancies group due to improved diagnostics $[7,11,29,30]$, which was not the case in our material where diagnostic procedures were almost the same as in the previous period. Lately the rising trend of undiagnosed cases [1, 5-8, 18, 24] can be attributed to the changes in the epidemiologic milieu [3], atypical disease presentation [9, $10]$, strict criteria used in establishing the definitive 
diagnosis $[1,8,31]$ and with the improvement in diagnostic techniques, which enable many cases to be diagnosed rapidly and only the real difficult ones to enter the category of FUO.

The limitations of this investigation are its retrospective character, a small number of patients that does not allow finding more pronounced statistical significant differences in both diagnostic groups and diseases as well, and the used axillary measurement of the body temperature, which is a traditional procedure in this region [3], and at times it was also performed by others $[32,33]$. In the same way, we could not apply some of the most sophisticated diagnostic tests (positron emission tomography scan, genetic investigations, fungal diagnostic, temporal artery biopsy) in any of the studied periods.

\section{CONCLUSION}

The spectrum of diseases causing FUO in the Republic of North Macedonia shows some changes over time. Although infections remain the most common causes, their occurrence nowadays is significantly reduced, whereas the frequencies of NIID, malignant and miscellaneous diseases tended to be slightly elevated, with a more pronounced increase of undiagnosed cases. Also, during the two studied periods we noted fluctuations in the incidence of certain diseases from all diagnostic categories. Clinical evaluation even today in the era of highly sophisticated diagnostic techniques remains to be a vital tool in solving the aetiology of FUO. When dealing with FUO there is a necessity of enormous commitment to the patients, a good insight of the problem, familiarity with the regional epidemiologic situation and disease dynamics, as well as an interdisciplinary approach.

Conflict of Interest. The authors declare that there are no conflicts of interest.

Funding. No sources of support declared.

Introducere. Studiul a comparat spectrul etiologic al febrei de origine necunoscută (FUO) într-un spital din Republica de Nord Macedonia.

Materiale şi metode. Au fost analizate date retrospective la 185 de pacienți cu FUO tratați la Spitalul Universitar de Boli Infecțioase din Skopje. 79 de pacienți au fost internați între 1991 şi 1995 şi 106 intre 2011 şi 2015.

Rezultate. Comparînd cele două perioade, infecția a fost prezentă în $46.8 \%$ respectiv $29.2 \%(p=0.014)$, inflamațiile non-infecțioase in $22.8 \%$ respectiv $25.5 \%$ din cazuri, neoplasmele in $10.1 \%$ respectiv $13.2 \%(p=0.522)$, alte cauze $8.9 \%$ respectiv $12.3 \%(p=0.461)$, iar cazurile fără diagnostic in $11.4 \%$ respectiv $19.8 \%$ din cazuri $(p=0.124)$. Cele mai frecvente cauze a FUO în perioada 1991-1995 au fost abcesul (8.9\%), tuberculoza și lupusul eritematos sistemic (7.6\% fiecare). Cele mai frecvente cauze ale FUO în perioada 2011-2015 au fost boala Still a adultului, polimialgia reumatică (fiecare 7.6\%), abcesul şi leishmanioza viscerală ( fiecare $5.7 \%$ ). Tehnicile noi imagistice au avut capacitate superioară de diagnostic în cea de-a doua perioadă evaluată.

Concluzii. S-a observat o schimbare a spectrului etiologic al FUO. Infecțiile continuă să aibă o pondere importantă însă cu o scădere a incidenței. Evaluarea clinică şi urmărirea pacienților sunt vitale pentru diagnosticul etiologic FUO.

Correspondence to: Mile Bosilkovski, M.D, Ph.D, University Hospital for Infectious Diseases and Febrile Conditions, Medical Faculty "Ss Cyril and Methodius" University, ul "Bozidar Adzija" br. 18/1-6 1000 Skopje, R. of North Macedonia, Tel +389 71238530

E-mail:milebos@yahoo.com

\section{REFERENCES}

1. VANDERSCHUEREN S., KNOCKAERT D., ADRIAENSSENS T., DEMEY W., DURNEZ A., BLOCKMANS D., et al. From prolonged febrile illness to fever of unknown origin: the challenge continues. Arch Intern Med. 2003;163:1033-41.

2. HIRSCHMANN JV. Fever of unknown origin in adults. Clin Infect Dis. 1997;24:291-300.

3. BOSILKOVSKI M., DIMZOVA M., STEVANOVIĆ M., CVETKOVSKA VS., DUGANOVSKA MV. Fever of unknown origin-diagnostic methods in a European developing country. Vojnosanit Pregl. 2016;73:553-8. 
4. IIKUNI Y., OKADA J., KONDO H., KASHIWAZAKI S. Current fever of unknown origin 1982-1992. Intern Med. 1994;33:67-73.

5. KUCUKARDALI Y., ONCUL O., CAVUSLU S., DANACI M., CALANGU S., ERDEM H., et al. The spectrum of diseases causing fever of unknown origin in Turkey: a multicenter study. Int J Infect Dis. 2008; 12:71-9.

6. LARSON EB., FEATHERSTONE HJ., PETERSDORF RG. Fever of undetermined origin: diagnosis and follow-up of 105 cases, 1970-1980. Medicine (Baltimore). 1982;61:269-92.

7. MOURAD O., PALDA V., DETSKY AS. A comprehensive evidence-based approach to fever of unknown origin. Arch Intern Med. 2003;163:545-51.

8. KNOCKAERT DC., VANDERSCHUEREN S., BLOCKMANS D. Fever of unknown origin in adults: 40 years on. J Intern Med. 2003;253:263-75.

9. VARGHESE GM., TROWBRIDGE P., DOHERTY T. Investigating and managing pyrexia of unknown origin in adults. BMJ. 2010;341:c5470.

10. HERSCH EC., OH RC. Prolonged febrile illness and fever of unknown origin in adults. Am Fam Physician. 2014;90:91-6.

11. KASHIWAGI H. Fever of unknown origin: a changing diagnostic spectrum. Intern Med. 1994;33:65-6.

12. EFSTATHIOU SP., PEFANIS AV., TSIAKOU AG., SKEVA II., TSIOULOS DI., ACHIMASTOS AD., et al. Fever of unknown origin: discrimination between infectious and non-infectious causes. Eur J Intern Med. 2010;21:137-43.

13. BAYMAKOVA M., PLOCHEV K., DIKOV I., POPOV G., MIHAYLOVA-GARNIZOVA R., KOVALEVA R., et al. Fever of Unknown Origin in a Bulgarian Hospital: Evaluation of 54 Cases for a Four Year-Period. J Clin Anal Med. 2016;7:70-5.

14. BAYMAKOVA M., SAKEM B., PLOCHEV K., MIHAYLOVA-GARNIZOVA R., KOVALEVA V., POPOV G., et al. Fever of unknown origin in adults: two case reports and review. J Clin Anal Med. 2014;5:348-51.

15. BAICUS C., BOLOSIU HD., TANASESCU C., BAICUS A. Fever of unknown origin-predictors of outcome. A prospective multicenter study on 164 patients. Eur J Intern Med. 2003;14:249-54.

16. TURKULOV V., BRKIĆ S., SEVIĆ S., MARIĆ D., TOMIĆ S. Fever of unknown origin in elderly patients. Srp Arh Celok Lek. 2011;139:64-8.

17. POPOVSKA-JOVICIĆ B., CANOVIĆ P, GAJOVIĆ O., RAKOVIĆ I., MIJAILOVIĆ Z. Fever of unknown origin: Most frequent causes in adult patients. Vojnosanit Pregl. 2016;73:21-5.

18. SHI XC., LIU XQ., ZHOU BT., ZHANG LF., MA XJ., DENG GH., et al. Major causes of fever of unknown origin at Peking Union Medical College Hospital in the past 26 years. Chin Med J (Engl). 2013;126:808-12.

19. MONTASSER MF., ABDELKADER NA., MONTASSER IF., EL KHOULY AM. Changing the face of fever of unknown origin in Egypt: a single hospital study. Braz J Infect Dis. 2015;19:334-5.

20. PETERSDORF RG., LARSON E. FUO revisited. Trans Am Clin Climatol Assoc. 1983;94:44-54.

21. SHI Q., WANG C., XU D., LI F., REN A., WANG H., et al. An analysis of etiologies of fever of unknown origin in 372 patients. Zhonghua Nei Ke Za Zhi. 2014;53:298-302.

22. ABDELBAKY MS., MANSOUR HE., IBRAHIM SI., HASSAN IA. Prevalence of connective tissue diseases in Egyptian patients presenting with Fever of unknown origin. Clin Med Insights Arthritis Musculoskelet Disord. 2011;4:33-41.

23. BARBADO FJ., VAZQUEZ JJ., PENA JM., ARNALICH F., ORTIZ-VAZQUEZ J. Pyrexia of unknown origin: changing spectrum of diseases in two consecutive series. Postgrad Med J. 1992;68:884-7.

24. YAMANOUCHI M., UEHARA Y., YOKOKAWA H., HOSODA T., WATANABE Y., SHIGA T., et al. Analysis of 256 cases of classic fever of unknown origin. Intern Med. 2014;53:2471-5.

25. ALAVI SM., NADIMI M., ZAMANI GA. Changing pattern of infectious etiology of fever of unknown origin (FUO) in adult patients in Ahvaz, Iran. Caspian J Intern Med. 2013;4:722-6.

26. KEJARIWAL D., SARKAR N., CHAKRABORTI SK., AGARWAL V., ROY S. Pyrexia of unknown origin: a prospective study of 100 cases. J Postgrad Med. 2001;47:104-7.

27. SALTOGLU N., TASOVA Y., MIDIKLI D., AKSU HS., SANLI A., DUNDAR IH. Fever of unknown origin in Turkey: evaluation of 87 cases during a nine-year-period of study. J Infect. 2004;48:81-5.

28. YU KK., CHEN SS., LING QX., HUANG C., ZHENG JM., CHENG Q., et al. Fever of unknown origin: report of 107 cases in a university hospital. Int J Clin Exp Med. 2014;7:5862-6.

29. SHOJI S., IMAMURA A., IMAI Y., IGARASHI A., YAZAWA M., HIRAHARA K., et al. Fever of unknown origin: a review of 80 patients from the Shin'etsu area of Japan from 1986-1992. Intern Med. 1994;33:74-6.

30. KNOCKAERT DC., VANNESTE LJ., VANNESTE SB., BOBBAERS HJ. Fever of unknown origin in the 1980s. An update of the diagnostic spectrum. Arch Intern Med. 1992;152:51-5.

31. DE KLEIJN EM., VAN LIER HJ., VAN DER MEER JW. Fever of unknown origin (FUO). II. Diagnostic procedures in a prospective multicenter study of 167 patients. The Netherlands FUO Study Group. Medicine (Baltimore). 1997;76:401-14.

32. MACKOWIAK PA., WORDEN G. Carl Reinhold August Wunderlich and the evolution of clinical thermometry. Clin Infect Dis. 1994; 18:458-67.

33. NAITO T., MIZOOKA M., MITSUMOTO F., KANAZAWA K., TORIKAI K., OHNO S., et al. Diagnostic workup for fever of unknown origin: a multicenter collaborative retrospective study. BMJ Open. 2013;3:e003971. doi: 10.1136/bmjopen-2013-003971.

Received January 10, 2019 